\title{
Dispersal and dive patterns in gravid leatherback turtles during the nesting season in French Guiana
}

\author{
Sabrina Fossette ${ }^{1,2}$, Sandra Ferraroli ${ }^{1}$, Hideji Tanaka ${ }^{3,4,5}$, Yan Ropert-Coudert ${ }^{4}$, \\ Nobuaki Arai ${ }^{3}$, Katsufumi Sato ${ }^{4}$, Yasuhiko Naito ${ }^{4}$, Yvon Le Maho ${ }^{1}$, Jean-Yves Georges ${ }^{1, *}$ \\ ${ }^{1}$ Institut Pluridisciplinaire Hubert Curien-Département Ecologie, Physiologie et Ethologie, Université Louis Pasteur, \\ CNRS-7178, 23 rue Becquerel, 67087 Strasbourg, France \\ ${ }^{2}$ Université Louis Pasteur, 4 rue Blaise Pascal, 67070 Strasbourg, France \\ ${ }^{3}$ Department of Social Informatics, Graduate School of Informatics, Kyoto University, \\ Yoshida-Honmachi, Sakyo-ku, Kyoto 606-8501, Japan \\ ${ }^{4}$ National Institute of Polar Research, 1-9-10 Kaga, Itabashi-ku, Tokyo 173-8515, Japan \\ ${ }^{5}$ Present address: Graduate School of Fisheries Sciences, Hokkaido University, 3-1-1 Minato-cho, Hakodate 041-8611, Japan
}

\begin{abstract}
We present the first combined analysis of diving behaviour and dispersal data collected from gravid leatherback turtles during 3 consecutive nesting seasons in French Guiana. In total, 23 turtles were fitted with Argos satellite transmitters and 16 individuals (including 6 that were concurrently satellite-tracked) were equipped with an electronic time-depth recorder for single internesting intervals, i.e. between 2 consecutive ovi-positions. The leatherbacks dispersed over the continental shelf - from the coastal zone to the shelf break - and moved over $546.2 \pm 154.1 \mathrm{~km}$ (mean \pm SD) in waters of French Guiana and neighbouring Suriname. They mostly performed shallow $(9.4 \pm$ $9.2 \mathrm{~m})$ and short $(4.4 \pm 3.4 \mathrm{~min})$ dives with a slight diurnal pattern. They dived deeper as they moved away from the coast, suggesting that they were predominantly following the seabed. Inter-nesting intervals could be divided into 2 phases: the first comprised $75 \%$ of the time turtles spent at sea, during which they dived on average $47 \mathrm{~min} \mathrm{~h}^{-1}$, while the second was characterised by lower and more variable diving effort as the turtles returned to shore. The extended movements of leatherbacks and the fine analysis of dive shapes suggest that, in French Guiana, leatherbacks may feed during the inter-nesting interval, probably to compensate for the energy costs associated with reproduction. Consequently, this critically endangered species is exposed to a high risk of interaction with local fisheries over the continental shelf.
\end{abstract}

KEY WORDS: Marine turtles - Dermochelys coriacea - Diving behaviour - Bottom phase · Continental shelf $\cdot$ Foraging strategy $\cdot$ Satellite tracking $\cdot$ French Guiana

-Resale or republication not permitted without written consent of the publisher

\section{INTRODUCTION}

An understanding of how wild animals face tradeoffs between survival and reproduction is important for species with high reproductive effort, particularly for critically endangered species where adult mortality may be high enough to result in extinction. In sea turtles, reproduction takes place over 2 mo during which females lay 1 to 14 clutches of 50 to 130 eggs each, depending on the species (Miller 1997). Accordingly, sea turtles have high reproductive energy costs (IUCN RedList, available at: www.iucnredlist.org). Among sea turtles, the critically endangered leatherback turtle Dermochelys coriacea shows the highest reproductive output (Miller 1997): it may lay the equivalent of $20 \%$ of its body mass (J. Y. Georges et al. unpubl. data), and supposedly does not feed over the nesting season (Miller 1997, Rivalan et al. 2005). 
Consequently, during the inter-nesting intervals, leatherbacks might minimise energy expenditure to maximize the amount of energy allocated to oviposition and egg production (Reina et al. 2005, Wallace et al. 2005). This seems to be the case for gravid leatherbacks nesting along the Pacific coast of Costa Rica, which have been reported to move very slowly near the seabed (Reina et al. 2005) and display an extremely low metabolic rate (Wallace et al. 2005) during the nesting season.

In contrast, the gravid leatherbacks nesting on both sides of the Atlantic cover great distances at sea (Georges et al. 2007, this volume) and swim at high speed during inter-nesting intervals (Eckert et al. 1989, Eckert 2002). Atlantic leatherbacks nesting in the Caribbean perform shallow nocturnal dives and deep diurnal dives (Eckert et al. 1989), consistent with the vertical migration of their main prey (i.e. gelatinous plankton; Hays 2003) and indicative of nocturnal foraging activity (Myers \& Hays 2006). In other words, between 2 consecutive nesting events, leatherback turtles may compensate for high reproductive costs either by reducing their activity or by feeding, as suggested for the Pacific and Atlantic populations, respectively.

The diving behaviour of marine animals has been studied in several different ways, such as by analysing depth profiles concurrently with e.g. swim speed (e.g. Eckert 2002, Ropert-Coudert et al. 2000), 3-dimensional compass data (e.g. Mitani et al. 2003) or underwater video (e.g. Reina et al. 2005, Watanabe et al. 2006). Concurrent study of diving and dispersal behaviour (Georges et al. 1997) provides important information regarding the areas in which particular behaviours occurs, and defines the oceanic zones where individuals tend to congregate. Such information is crucial for the management of protected species whose distribution overlaps with areas of natural and/or anthropogenic threats (e.g. Georges et al. 2007).

Here we present the first combined analysis of diving and dispersal patterns of the critically-endangered leatherback turtle, inferred from data collected during their inter-nesting intervals over 3 consecutive nesting seasons in French Guiana. Following the extended dispersal reported for this population (Georges et al. 2007), we predicted that leatherbacks in French Guiana do not reduce their activity, as suggested for populations in the Pacific Ocean (Reina et al. 2005), but rather dive consistently and display feeding activity, as suggested for the Caribbean Sea (Eckert et al. 1989, Myers \& Hays 2006). In addition, because leatherbacks face lethal interactions with industrial fisheries while dispersing widely over the continental shelf in French Guiana (Delamare 2005, Georges et al. 2007), our study aimed to identify those areas and depths where these interactions are more likely to occur.

\section{MATERIALS AND METHODS}

The study was conducted during the nesting seasons between 2001 and 2003 at Awala-Yalimapo Beach $\left(5.7^{\circ} \mathrm{N}, 53.9^{\circ} \mathrm{W}\right)$, French Guiana, on the border with Suriname, South America (Fig. 1).

Horizontal movements. During the study period, 23 females were equipped with satellite platform transmitter terminals (PTTs; Kiwisat 101, AA-cell, $150 \mathrm{~g}$, cross-section $4 \mathrm{~cm}^{2}$, Sirtrack). PTTs were held in place on the carapace using a customised harness attached during ovi-position in 2001 (see Eckert et al. 1996), and were directly fixed on the central ridge of the turtle's
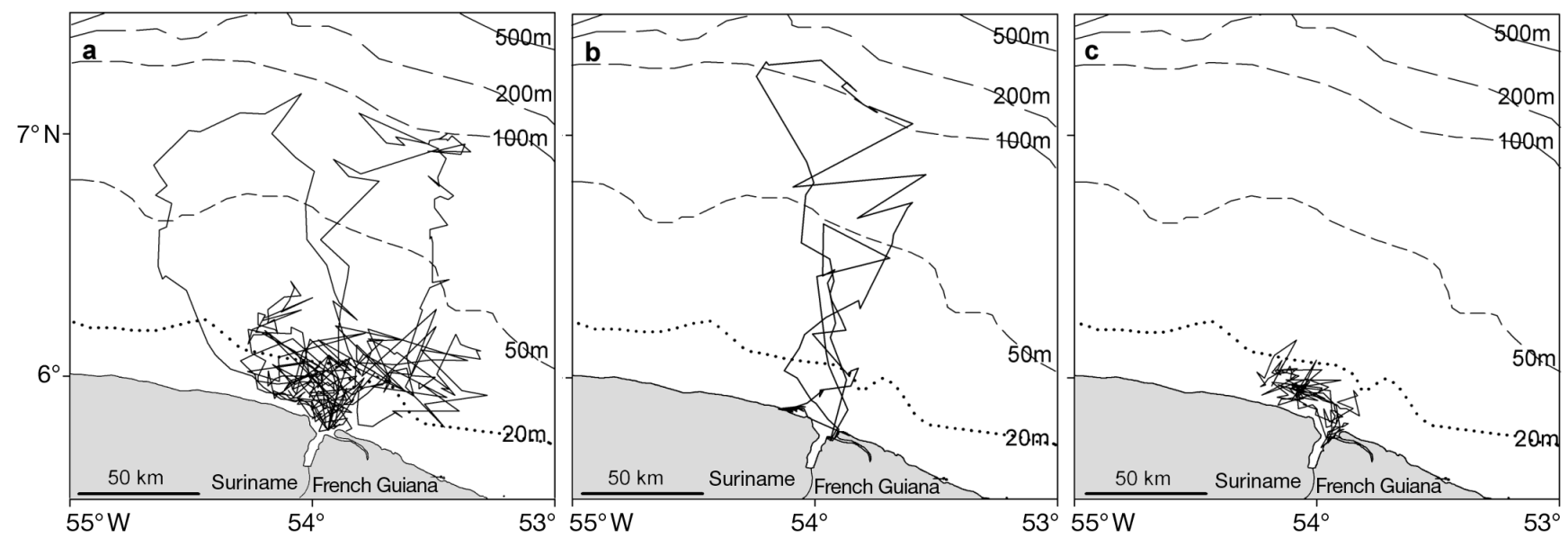

Fig. 1. Dermochelys coriacea. Inter-nesting movements performed by 11 gravid leatherback turtles in relation to bathymetry in French Guiana in (a) $2001(\mathrm{n}=7),(\mathrm{b}) 2002(\mathrm{n}=2)$ and (c) $2003(\mathrm{n}=2)$ 
carapace in 2002 and 2003 (see Southwood et al. 1999). Harnesses were automatically released from the animals after several months (during post-nesting migrations) due to a corrodible link in the attachment system (Eckert et al. 1996). PTTs directly fixed on the carapace were removed as soon as turtles came back to the nesting beach after at least 1 inter-nesting interval.

At-sea movements were reconstructed using the Argos system (www.argosinc.com). Each Argos location was provided with a class of accuracy, with classes 1, 2 and 3 having nominal standard deviations around the true position of 1000, 350 and $150 \mathrm{~m}$, respectively; location classes A, B and 0 have no designed accuracy. We analysed all locations of all accuracies, excluding locations that were on land, locations separated by less than $1 \mathrm{~h}$ and locations that implied travel rates of $>10 \mathrm{~km} \mathrm{~h}^{-1}$ (Eckert 2002, Gaspar et al. 2006) by filtering out the least accurate locations.

For individual turtles tracked during more than 1 inter-nesting interval, we only considered the first track to avoid pseudo-replication. For each individual track, we calculated the time spent at sea, the overall distance travelled, and the distance of the furthest point from the beach (dispersal range). Each track was divided into phases according to the distance that turtles moved relative to the beach. Outbound/inbound phases corresponded to the period when turtles moved away from/towards the beach, respectively. For some individuals, an intermediate phase between outbound and inbound phases was identified, i.e. when the distance to the beach remained close to its maximum value.

Vertical movements. Sixteen females fitted with PTTs were concurrently equipped with an electronic Time-Depth Recorder (TDR 54 g, cross-section $3.5 \mathrm{~cm}^{2}$, length $116 \mathrm{~mm}$, Little Leonardo), directly fixed on the central ridge of the turtle's carapace for a single inter-nesting interval. Each logger included a pressure sensor that measured depth (range: 0 to $100 \pm 0.05 \mathrm{~m}$ ) every second. Following recapture, loggers were removed and data downloaded onto a laptop computer. Data were analysed using IGOR Pro software (WaveMetrics). All dives $>0.5 \mathrm{~m}$ and $<2 \mathrm{~m}(\mathrm{n}=48220)$ occurred exclusively during the first $1.5 \mathrm{~h}$ and the last $6 \mathrm{~h}$ of each individual inter-nesting interval, probably reflecting travel from/to the nesting beach, and were excluded from the analysis to allow us to focus on other diving patterns. We recorded the start and end time of each dive, the maximum depth reached, the duration of descent/bottom/ascent phases, the rates of descent and ascent, and the duration of the preceding and subsequent post-dive surface interval. The bottom phase was defined as the period during which depth was greater than $90 \%$ of the maximum depth of a given dive. For each bottom phase, we calculated the depth amplitude and number of rapid, up-and-down undulations observed in the depth profile (hereafter termed 'wiggles'; see Wilson 1995, Houghton et al. 2002).

In order to classify dive profiles, a principal component analysis (PCA) was performed on all 20607 dives $>2 \mathrm{~m}$, taking the above-mentioned parameters into account. As the total number of dives recorded varied among individuals (from 679 to 3539 dives), relationships among dive parameters were analysed using a random sample of 600 dives per individual. This avoided pseudo-replication while taking inter-individual variability into account (Cherel et al. 1999). Diel patterns (in terms of number of dives, dive depth and dive duration) were investigated by using the nautical definition of dawn and dusk (i.e. when the sun was $12^{\circ}$ below the horizon at Awala-Yalimapo Beach; www.usno.navy.mil). Dive effort was analysed by considering hourly dive frequency and time spent diving per hour. Changes in hourly diving effort were investigated throughout the inter-nesting interval in $12 \mathrm{~h}$ increments centred on midnight and midday, excluding $12 \mathrm{~h}$ blocks that were incomplete (i.e. for the first and last hours of the trip). Statistical analyses were performed using Minitab statistical software. Values are given as mean $\pm \mathrm{SD}$, differences being considered as statistically significant when $\mathrm{p}<0.05$.

All turtles were measured during ovi-position using a flexible measuring tape $( \pm 0.5 \mathrm{~cm})$ following Georges \& Fossette (2006). Standard curvilinear carapace length was measured on the midline of the shell, from the nape notch of the carapace to the end of the caudal peduncle. Curvilinear carapace width was measured at the maximum width posterior to the fore-flippers (Georges \& Fossette 2006).

\section{RESULTS}

Among the 23 females equipped with Argos transmitters, we obtained data from 11 individuals 7 in 2001, 2 in 2002 and 2 in 2003) over at least 1 complete inter-nesting interval (Table 1). Among the 16 individuals that were fitted with TDRs, 10 were successfully recaptured with their tag, of which 7 (3 in 2001, 2 in 2002 and 2 in 2003; Table 2) were monitored over 1 complete inter-nesting interval. Four individuals were concurrently monitored with Argos and TDR devices over 1 complete inter-nesting interval.

\section{Horizontal movements}

Most locations obtained from Argos were of poor quality, with locations $3,2,1,0$ and below contributing to $4,8,14,13$ and $60 \%$ of the total number of locations 
Table 1. Dermochelys coriacea. Summary of inter-nesting movements performed by 11 tracked leatherback turtles nesting in French Guiana in 2001, 2002 and 2003; 6 turtles were simultaneously equipped with TDR (+; see Table 2)

\begin{tabular}{|c|c|c|c|c|c|c|c|c|c|}
\hline $\begin{array}{l}\text { Turtle } \\
\text { ID }\end{array}$ & TDR & $\begin{array}{c}\text { Departure date, } \\
\text { time (h) }\end{array}$ & $\begin{array}{l}\text { Trip } \\
\text { duration } \\
\text { (d) }\end{array}$ & $\begin{array}{l}\text { Dispersal } \\
\text { range } \\
(\mathrm{km})\end{array}$ & $\begin{array}{c}\text { Total travelled } \\
\text { distance } \\
(\mathrm{km})\end{array}$ & $\begin{array}{c}\text { Outbound } \\
\text { duration }(\mathrm{d}) \\
\text { distance }(\mathrm{km})\end{array}$ & $\begin{array}{c}\text { Middle stage } \\
\text { duration }(\mathrm{d}) \\
\text { distance }(\mathrm{km})\end{array}$ & $\begin{array}{c}\text { Return } \\
\text { duration }(\mathrm{d}) ; \\
\text { distance }(\mathrm{km})\end{array}$ & $\begin{array}{c}\text { No. of } \\
\text { locations }\end{array}$ \\
\hline 200101 & + & 16 May 01, 03:30 & 10.8 & 154.8 & 534.9 & $5.2 ; 264.6$ & $0.0 ; 0.0$ & $5.5 ; 270.3$ & 56 \\
\hline 200102 & + & 22 May 01, 06:00 & 9.9 & 70.4 & 399.1 & $3.0 ; 188.4$ & $1.9 ; 58.0$ & $5.0 ; 222.7$ & 101 \\
\hline 200103 & + & 29 May 01, 02:45 & 10.1 & 54.1 & 464.2 & $2.1 ; 134.3$ & $4.7 ; 269.4$ & $3.3 ; 60.5$ & 43 \\
\hline 200104 & - & 29 Jun 01, 01:30 & 11.3 & 146.5 & 771.6 & $3.8 ; 318.3$ & $0.0 ; 0.0$ & $7.5 ; 453.3$ & 114 \\
\hline 200105 & - & 22 Jul 01, 07:30 & 10.0 & 75.9 & 846.6 & $3.1 ; 281.6$ & $2.9 ; 260.3$ & $4.1 ; 304.8$ & 87 \\
\hline 200106 & - & 26 Apr 01, 00:30 & 8.3 & 53.7 & 375.7 & $0.5 ; 34.9$ & $6.7 ; 232.9$ & $1.9 ; 107.9$ & 42 \\
\hline 200107 & - & 01 Jun 01, 03:30 & 11.8 & 78.5 & 598.4 & $2.1 ; 113.1$ & $2.4 ; 58.5$ & $7.3 ; 426.8$ & 56 \\
\hline 200203 & + & 16 Мау $02,02: 15$ & 10.6 & 99.4 & 411.8 & $2.1 ; 148.0$ & $0.0 ; 0.0$ & $8.5 ; 263.8$ & 47 \\
\hline 200204 & - & 03 Jun 02, 03:20 & 10.2 & 176.0 & 641.8 & $2.8 ; 193.7$ & $0.0 ; 0.0$ & $7.4 ; 448.1$ & 51 \\
\hline 200301 & + & 05 May 03, 21:26 & 9.3 & 37.1 & 464.9 & $0.6 ; 51.5$ & $7.0 ; 325.4$ & $1.8 ; 88.0$ & 84 \\
\hline 200303 & + & 07 May 03, 02:33 & 10.2 & 47.9 & 498.6 & $2.5 ; 126.1$ & $6.2 ; 293.6$ & $1.4 ; 78.9$ & 134 \\
\hline \multicolumn{3}{|c|}{ Mean \pm SD } & $10.2 \pm 0.9$ & $90.4 \pm 47.7$ & $546.2 \pm 154.1$ & $\begin{array}{r}2.5 \pm 1.3 \\
162.2 \pm 92.3\end{array}$ & $\begin{array}{c}2.9 \pm 2.8 \\
136.2 \pm 137.6\end{array}$ & $\begin{aligned} 4.9 & \pm 2.6 \\
247.7 & \pm 150.9\end{aligned}$ & $74.1 \pm 31.7$ \\
\hline
\end{tabular}

received, respectively. The 11 turtles spent on average $10.2 \pm 0.9 \mathrm{~d}$ (range 8.3 to $11.8 \mathrm{~d}$ ) at sea between 2 consecutive nesting events (Table 1). Turtles dispersed within a short range from the coast $(90.4 \pm 47.7 \mathrm{~km}$, range 37.1 to $176.0 \mathrm{~km})$, remaining over the shallow continental shelf $(<200 \mathrm{~m}$ depth), even though they moved over hundreds of kilometres $(546.2 \pm 154.1 \mathrm{~km}$, range 375.7 to $846.6 \mathrm{~km}$ ) within waters of French Guiana and neighbouring Suriname (Fig. 1, Table 1). Four turtles remained within $50 \mathrm{~km}$ of Awala-Yalimapo Beach, where they moved erratically in shallow waters (approx. $20 \mathrm{~m}$ depth). Four other turtles remained within $100 \mathrm{~km}$ of the beach, reaching waters approx. $50 \mathrm{~m}$ deep, while the last 3 individuals reached the edge of the continental shelf where depth is $\sim 100 \mathrm{~m}$. Among the 7 turtles that moved over significant distances, 2 headed west into Surinamese waters, where they tended to move anticlockwise before swimming along the coast towards the nesting beach. The 5 other turtles remained in French Guianian waters east of Awala-Yalimapo Beach, and tended to move clockwise until they crossed their initial path off the Maroni River. They then reached Surinamese waters, where they moved anticlockwise before swimming along the coast towards the nesting beach.

There was no significant relationship between turtle biometry (standard curvilinear carapace length and curvilinear carapace width) and trip duration (Spearman rank correlation, $\mathrm{r}_{\mathrm{S}}=-0.19, \mathrm{p}=0.65$ and $\mathrm{r}_{\mathrm{S}}=0.12$, $\mathrm{p}=0.77$ for carapace length and width, respectively, $\mathrm{n}=8$ turtles; 3 of the 11 turtles were not measured), dispersal range $\left(r_{S}=-0.40, p=0.32\right.$ and $r_{S}=0.17, p=$ 0.69 for length and width, respectively) or total distance travelled $\left(r_{\mathrm{S}}=-0.12, \mathrm{p}=0.78\right.$ and $\mathrm{r}_{\mathrm{S}}=0.37, \mathrm{p}=$ 0.37 for length and width, respectively).

\section{Vertical movements}

General characteristics

A total of 20607 dives $>2$ m was recorded by the 10 turtles; the longest dive was $28.2 \mathrm{~min}$ and attained a maximum depth of $63.9 \mathrm{~m}$, while the deepest dive was $83.8 \mathrm{~m}$ and was of $17.9 \mathrm{~min}$ duration (Table 2). Turtles performed mostly shallow $(9.4 \pm 9.2 \mathrm{~m})$ and short $(4.4 \pm$ $3.4 \mathrm{~min}$ ) dives, with substantial variation among individuals (Table 2). Dives shallower than 8 and $25 \mathrm{~m}$ represented 50 and $90 \%$ of the 6000 randomly sampled dives, respectively (Fig. 2a). Dives shorter than 4 and $10 \mathrm{~min}$ represented 50 and $90 \%$ of the 6000 randomly sampled dives, respectively (Fig. 2b). Dives deeper than $40 \mathrm{~m}$ ( $\mathrm{n}=$ 92) were performed by 1 single individual (Turtle 200101); these dives lasted on average 15.3 $\pm 3.1 \mathrm{~min}$ and did not significantly increase in duration with increasing depth (from 40 to 85 m; ANOVA, $F_{8,91}=2.02, \mathrm{p}=0.06$ ). Within a dive, the time spent in the bottom phase lasted a mean of $1.6 \pm 1.8 \mathrm{~min}$, corresponding to $32.8 \pm 16.0 \%$ (range 1 to $90 \%$ ) of total dive duration (Table 2). Wiggles occurred in the bottom phase of most of the dives: 50 and $90 \%$ of the dives showed $<12$ and $<40$ wiggles, respectively, with a mean of $16.3 \pm 17.5$ wiggles per dive (Fig. 3). Mean surface interval was $1.4 \pm 1.9 \mathrm{~min}$ (Table 2).

Due to dive depth distribution, the relationships between dive depth and other dive parameters were investigated by using $5 \mathrm{~m}$ dive depth increments between 2 and $40 \mathrm{~m}$ (individual relations were calculated with 600 random dives per turtle, except Turtle 200101 [n $=508$ dives, since 92 of those 600 randomly selected dives were $>40 \mathrm{~m}$ ]; therefore, $\mathrm{n}_{\text {total }}=5908$ dives; Fig. 4 ). Mean dive duration increased significantly with increasing depth class when considering either each 


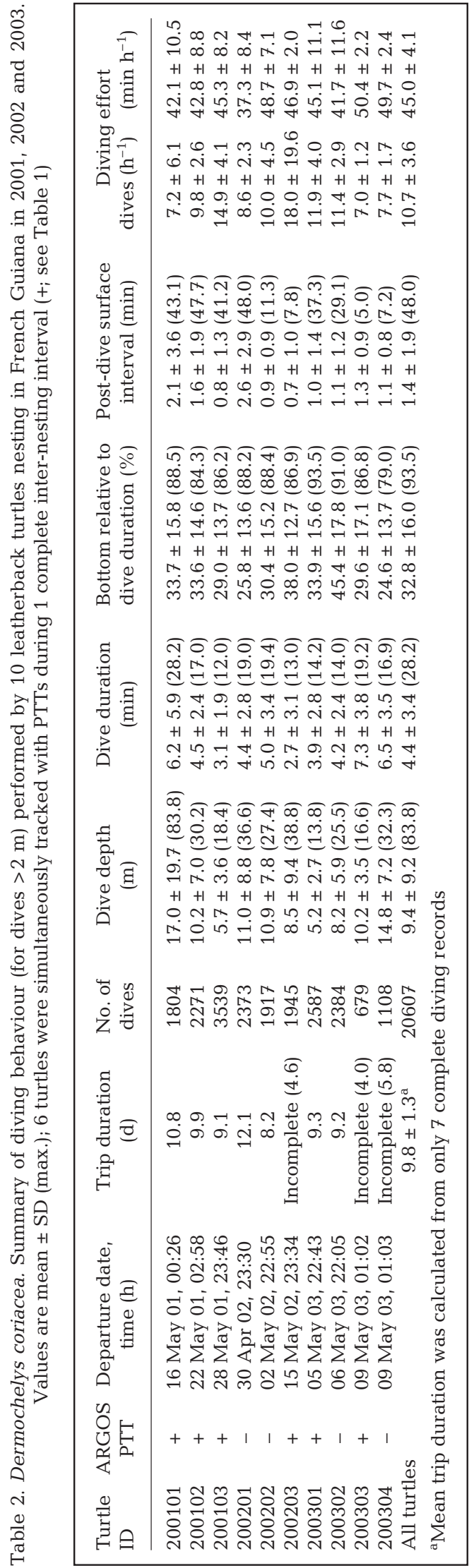

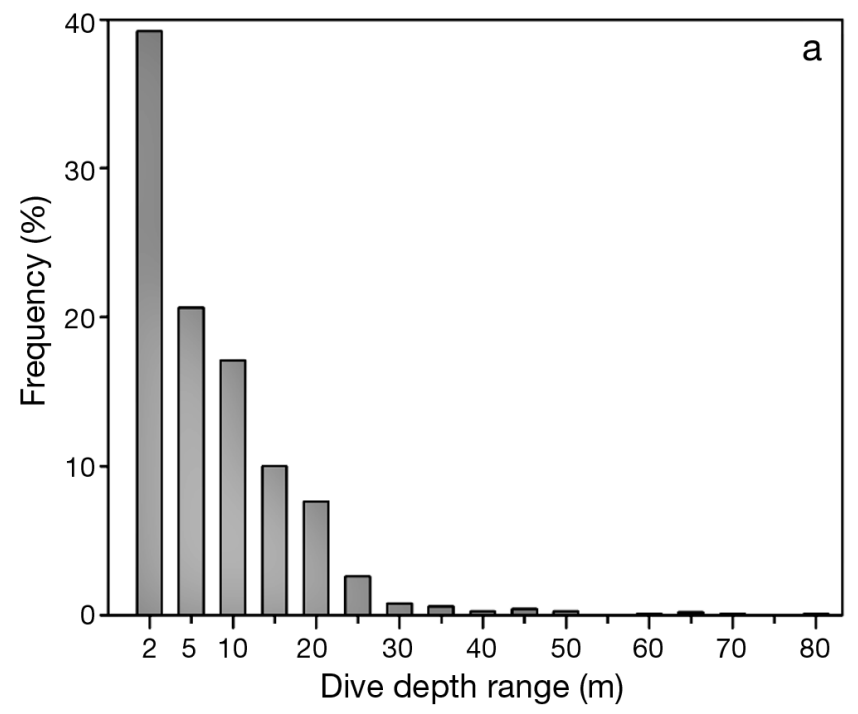

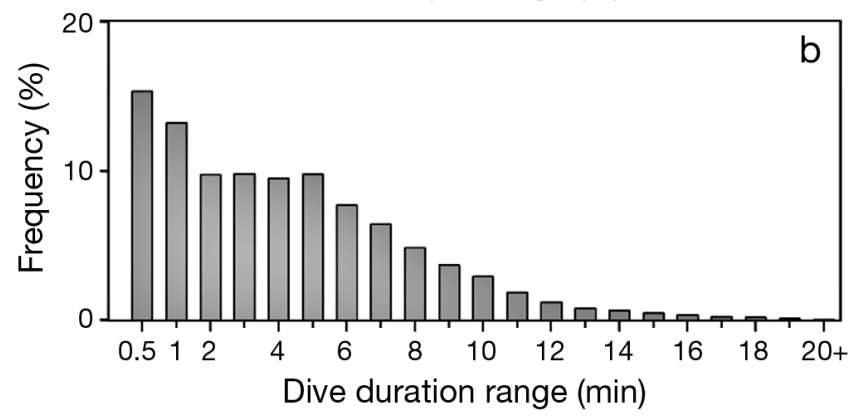

Fig. 2. Dermochelys coriacea. Frequency distribution of (a) dive depth and (b) dive duration ( $\mathrm{n}=6000$ dives) in 10 gravid leatherback turtles during their inter-nesting interval in French Guiana in 2001, 2002 and 2003

turtle individually (Spearman rank correlation, $\mathrm{p}<0.05$ in all cases) or all turtles together (Spearman rank correlation between the grand mean and depth classes, $\mathrm{r}_{\mathrm{S}}$ $=0.97, \mathrm{n}=10, \mathrm{p}<0.001$ ). There was no significant relationship between mean bottom time and depth class when considering either each turtle individually (Spearman rank correlation, $\mathrm{p}>0.05$ in all cases) or all turtles together $\left(\mathrm{r}_{\mathrm{S}}=0.24, \mathrm{n}=10, \mathrm{p}=0.57\right)$. When considering all individuals together, both rates of descent and ascent were significantly related to dive depth $\left(\mathrm{r}_{\mathrm{S}}=\right.$ $0.95, \mathrm{n}=10, \mathrm{p}<0.001$ and $\mathrm{r}_{\mathrm{S}}=0.90, \mathrm{n}=10, \mathrm{p}<0.01$, respectively, Fig. 4). However, when considered individually, these relationships did not hold for several turtles (descent rate: turtles 200103, 200202, 200203, 200301, 200303 and 200304; ascent rate: turtles 200101, 200103, 200203, 200301，200302，20303 and 200304). Turtles descended and ascended at about $0.1 \mathrm{~m} \mathrm{~s}^{-1}$ for dives $<15 \mathrm{~m}$, and regularly increased their rate of vertical travel for deeper depths with a mean maximum rate of $0.26 \pm 0.06 \mathrm{~m} \mathrm{~s}^{-1}\left(\mathrm{n}_{\text {total }}=5908\right.$ dives; Fig. 4$)$.

There were significant relationships between preceding surface interval and dive duration when each turtle was considered individually (Pearson rank corre- 

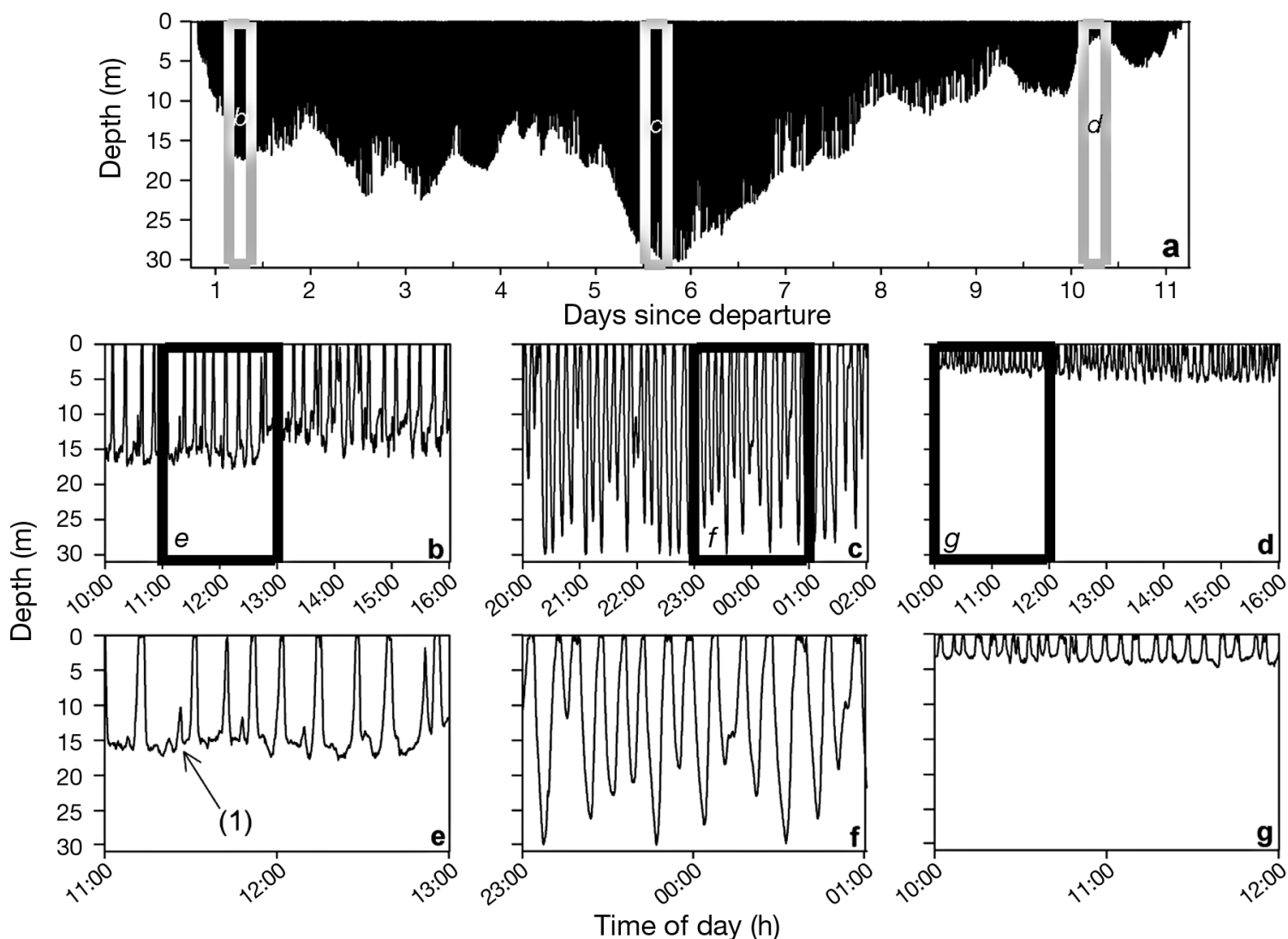

Fig. 3. Dermochelys coriacea. (a) Dive profile of Turtle 200102 during a simple inter-nesting interval in French Guiana (see Table 1); (b,c,d) enlarged profiles of $6 \mathrm{~h}$ at the start $(b)$, middle $(c)$ and end $(d)$ of the inter-nesting interval, respectively; $(\mathbf{e}, \mathbf{f}, \mathbf{g})$ enlarged profiles of $2 \mathrm{~h}(e, f, g)$, illustrating Type 4, Type 2 and Type 1 dives, respectively (see 'Results' for details). Classical wiggle pattern illustrated by (1)

lation, $\mathrm{p}<0.05$ in all cases, $\mathrm{n}=600$ dives per turtle), with the exception of 4 individuals (turtles 200102, 200103, 200201, 200302; Pearson rank correlation, p > 0.2 in all cases, $\mathrm{n}=600$ dives per turtle). However, this relationship was not observed if all turtles were considered together $\left(\mathrm{r}^{2}=0.07, \mathrm{n}=6000\right.$ dives, $\left.\mathrm{p}=0.23\right)$. Similarly, there were significant relationships between post-dive surface interval and dive duration when each turtle was considered individually (Pearson rank correlation, $\mathrm{p}<0.05$ in all cases, $\mathrm{n}=600$ dives per turtle), with the exception of 3 individuals (turtles 200201, 200301, 200302; Pearson rank correlation, $p>0.1$ in all cases, $\mathrm{n}=600$ dives per turtle). However, this relationship was not observed when all turtles were considered together $\left(r^{2}=0.09, n=6000\right.$ dives, $\left.p=0.21\right)$.

\section{Dive types}

The PCA performed on dive parameters from the 20607 dives $>2 \mathrm{~m}$ identified 2 factors that explained 34 and $20 \%$ of the observed variance, respectively. Factor 1 and Factor 2 were predominantly associated with dive duration and bottom time, respectively, and enabled us to distinguish 4 main dive types (Figs. $3 \& 5$, Table 3). Type 1 dives were the shallowest and shortest dives, whereas Type 3 dives were the deepest and longest. Type 2 dives and Type 4 dives were of intermediate mean maximum dive depth and mean dive duration, but differed in their bottom time, with Type 2 having the shortest and Type 4 the longest bottom time (Figs. 3 \& 5, Table 3). In addition, Type 2 dives showed the slowest ascent rate of all dives (Table 3).

\section{Diel pattern}

There was no significant difference between the number of dives performed during daytime and nighttime over the entire inter-nesting interval $\left(\mathrm{n}_{\text {day }}=10296\right.$ dives vs. $\mathrm{n}_{\text {night }}=10311$ dives, $\left.\chi^{2}{ }_{1}=0.005, \mathrm{p}>0.05\right)$. Dives performed during daytime were significantly deeper and correspondingly longer $(9.9 \pm 9.2 \mathrm{~m} ; 4.6 \pm$ $3.3 \mathrm{~min})$ than those performed at night $(8.9 \pm 9.1 \mathrm{~m}, t$ test, $t=7.41, \mathrm{p}<0.01 ; 4.2 \pm 3.4 \mathrm{~min}, t$-test, $t=7.80, \mathrm{p}<$ 0.01 ; Fig. 6). Turtles performed on average $10.7 \pm 3.6$ 


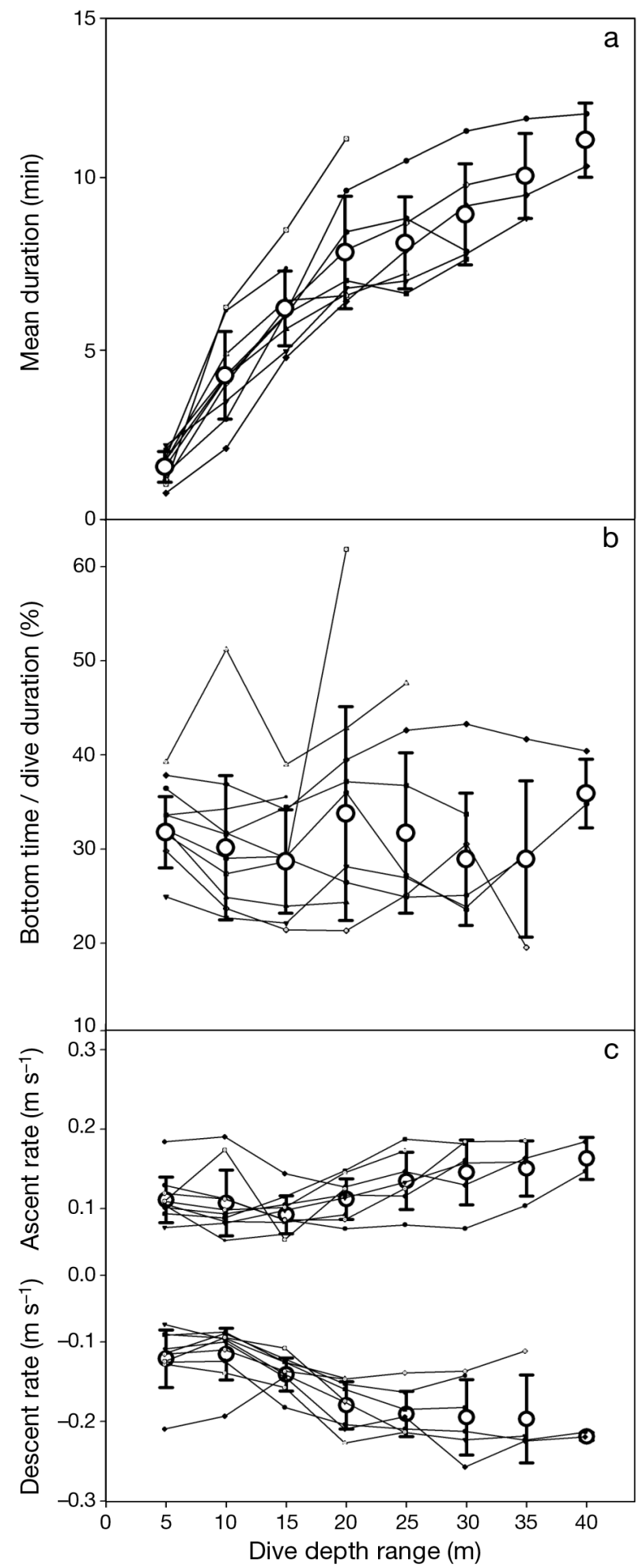

Fig. 4. Dermochelys coriacea. Relationships between dive depth and (a) dive duration, (b) proportion of time spent at the bottom of dives and (c) rates of descent and ascent in 10 gravid leatherback turtles during their inter-nesting interval in French Guiana in 2001, 2002 and 2003. Individual relationships were calculated from 600 random dives per turtle (except Turtle 200101: $\mathrm{n}=508$ dives, see 'Results'), from which means $(O ; \pm \mathrm{SD})$ were determined

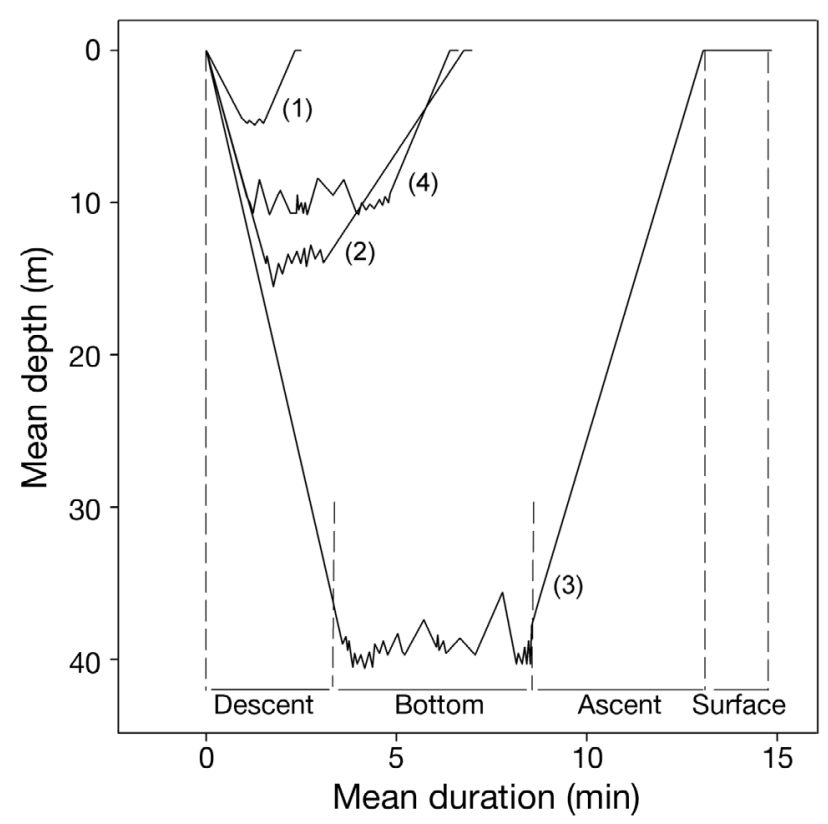

Fig. 5. Dermochelys coriacea. Schematic representation of 4 dive types (labelled 1 to 4) performed by 10 gravid leatherback turtles during their inter-nesting interval in French Guiana in 2001, 2002 and 2003 (see Table 3 for details). Dives consisted chronologically of a descent, bottom and ascent phase and a post-dive surface interval (shown here using Type 3 as an example)

dives $\mathrm{h}^{-1}$ (hourly dive frequency), corresponding to a mean time spent diving of $45.0 \pm 4.1 \mathrm{~min}^{-1}$ (Table 2). There was no significant difference between day and night either in terms of hourly dive frequency (MannWhitney $U$-test, $Z=107.0, \mathrm{n}=10, \mathrm{p}=0.9$ ) or in terms of time spent diving per hour (Mann-Whitney $U$-test, $Z=$ 123.0, $\mathrm{n}=10, \mathrm{p}=0.19$ ).

The 4 dive types were not equally distributed between day and night $\left(\chi^{2}{ }_{3}=374.6, \mathrm{n}=20607, \mathrm{p}<0.001\right.$; Fig. 7). Shallow Type 1 dives predominantly occurred during night-time $\left(\chi_{23}^{2}=134.1, \mathrm{n}=11733, \mathrm{p}<0.001\right.$, followed by a contrast test; Fig. 7), whereas Type 4 dives occurred mostly during the daytime $\left(\chi^{2}{ }_{23}=338.7\right.$, $\mathrm{n}=3186, \mathrm{p}<0.001$, followed by a contrast test; Fig. 7 ). Type 2 and Type 3 were equally distributed throughout the $24 \mathrm{~h}$ cycle $\left(\chi_{23}^{2}=13.2, \mathrm{n}=5105, \mathrm{p}>0.05\right.$ and $\chi_{23}^{2}=8.9, \mathrm{n}=583, \mathrm{p}>0.05$, respectively; Fig. 7).

\section{Integrating vertical and horizontal movements}

The 7 satellite-tracked turtles for which dive records were complete throughout the inter-nesting interval spent a mean of $9.8 \pm 1.3 \mathrm{~d}$ at sea between 2 consecutive nesting events (Table 2). This is similar to the $10.3 \pm 1.4 \mathrm{~d}$ spent at sea by the 5 individuals fitted only with PTTs (Mann-Whitney $U$-test, $Z=40, \mathrm{n}=12, \mathrm{p}=0.42$; Table 1 ). 


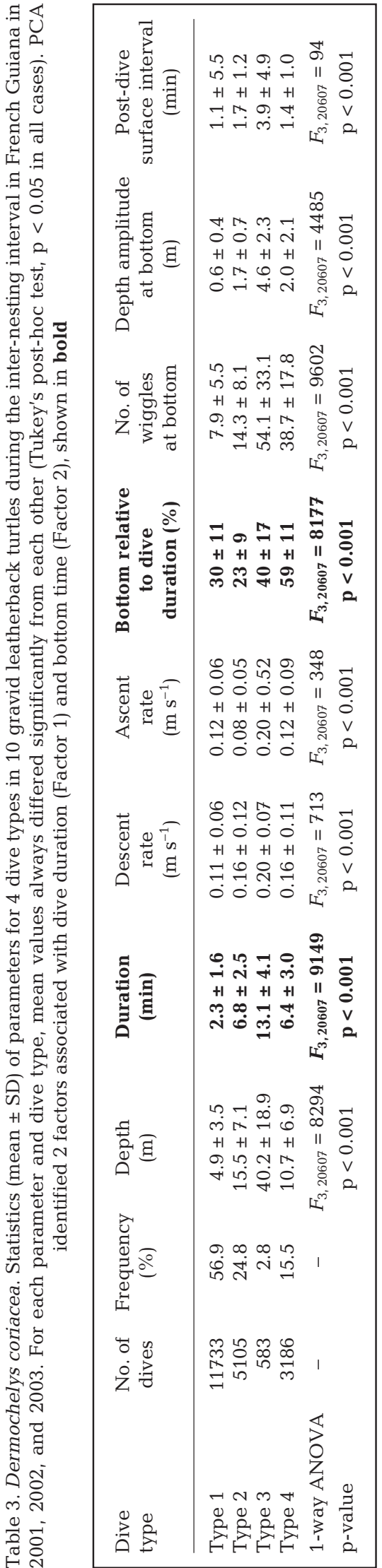

All 7 turtles dived continuously throughout the internesting interval but exhibited substantial changes in dive parameters over time (Figs. 8a \& 9). Among these 7 turtles with complete dive records, 4 individuals were also successfully tracked by Argos during the entire inter-nesting interval (Table 2). For these 4 turtles, maximum depth and mean depth increased with distance to the beach (Spearman rank correlation, $\mathrm{p}<$ 0.05 in all 4 cases; Fig. 8a,b).

Similarly, both indices of hourly diving effort varied significantly throughout the 7 inter-nesting intervals (Kruskal-Wallis, p < 0.05 in all cases; Figs. 8c \& 9), except in the case of Turtle 200202, for which time spent diving per hour did not vary significantly (KruskalWallis, $H_{16,191}=19.5, \mathrm{n}=192, \mathrm{p}=0.24$ ). For each internesting interval, 2 phases were identified according to the way that time spent diving per hour varied over time (Figs. 8c \& 9). Indeed, the time spent diving per hour was significantly higher during Phase 1 (47.3 \pm $\left.3.0 \mathrm{~min}^{-1}\right)$ than during Phase $2\left(31.3 \pm 6.7 \mathrm{~min}^{-1}\right.$, Mann-Whitney $U$-test, $Z=77.0, \mathrm{n}=7$ turtles, $\mathrm{p}<0.01$; Figs. 8c \& 9). Yet the hourly dive frequency did not differ significantly between Phase $1\left(9.7 \pm 3.0\right.$ dives $\left.\mathrm{h}^{-1}\right)$ and Phase $2\left(12.4 \pm 2.6\right.$ dives $\mathrm{h}^{-1}$, Mann-Whitney $U$ test, $Z=39.0, \mathrm{n}=7$ turtles, $\mathrm{p}=0.09$; Figs. 8c \& 9).

Phase 1 lasted a mean of $7.2 \pm 1.3$ d (i.e. about $75 \%$ of the inter-nesting interval), with significant differences in the time spent diving per hour apparent among individuals $\left(47.2 \pm 2.9 \mathrm{~min}^{-1}\right.$, ANOVA, $F_{6,104}=$ $14.0, \mathrm{n}=7$ turtles, $\mathrm{p}<0.001$ ) due to a particularly low value for 1 individual (Turtle 200201, $40.9 \pm 4.4 \mathrm{~min}$ $\mathrm{h}^{-1}$, Tukey's post-hoc test) compared with the 6 others, which did not differ $\left(48.3 \pm 1.4 \mathrm{~min} \mathrm{~h}^{-1}\right.$, ANOVA, $F_{5,86}=$ $1.6, \mathrm{n}=6$ turtles, $\mathrm{p}=0.17$ ). Similarly, during that first phase, the hourly dive frequency differed substantially among individuals $\left(9.7 \pm 3.0\right.$ dives $\mathrm{h}^{-1}$, ANOVA, $F_{6,104}=$ 12.4, $\mathrm{n}=7$ turtles, $\mathrm{p}<0.001)$. Turtles performed deeper, but fewer, dives as they moved away from the coast (Figs. 8b,c \& 9). Turtles that remained within $50 \mathrm{~km}$ of the coast (Turtles 200103 and 200301) performed $13.0 \pm 1.9$ dives $\mathrm{h}^{-1}$, which were mostly short and shallow Type 1 dives $(47.0 \pm 18.8 \%$ of their recorded dives). Turtle 200102, which dispersed between 50 and $100 \mathrm{~km}$ from the beach, performed $8.8 \pm 2.4$ dives $\mathrm{h}^{-1}$ that were predominantly intermediate-depth Type 2 and Type 4 dives $(40.5 \pm 20.3$ and $31.9 \pm 20.8 \%$ of her recorded dives, respectively). Finally, Turtle 200101 travelled more than $100 \mathrm{~km}$ from the beach and performed the fewest dives $\left(5.0 \pm 3.0\right.$ dives $\left.\mathrm{h}^{-1}\right)$; however, most of them $(69.1 \pm 55.5 \%)$ were long and deep Type 3 dives.

Phase 2 lasted a mean of $2.6 \pm 1.8$ d (i.e. about $25 \%$ of the inter-nesting interval). For each turtle, this phase was highly variable in terms of hourly diving effort (Figs. 8c \& 9). However, the time spent diving per hour 


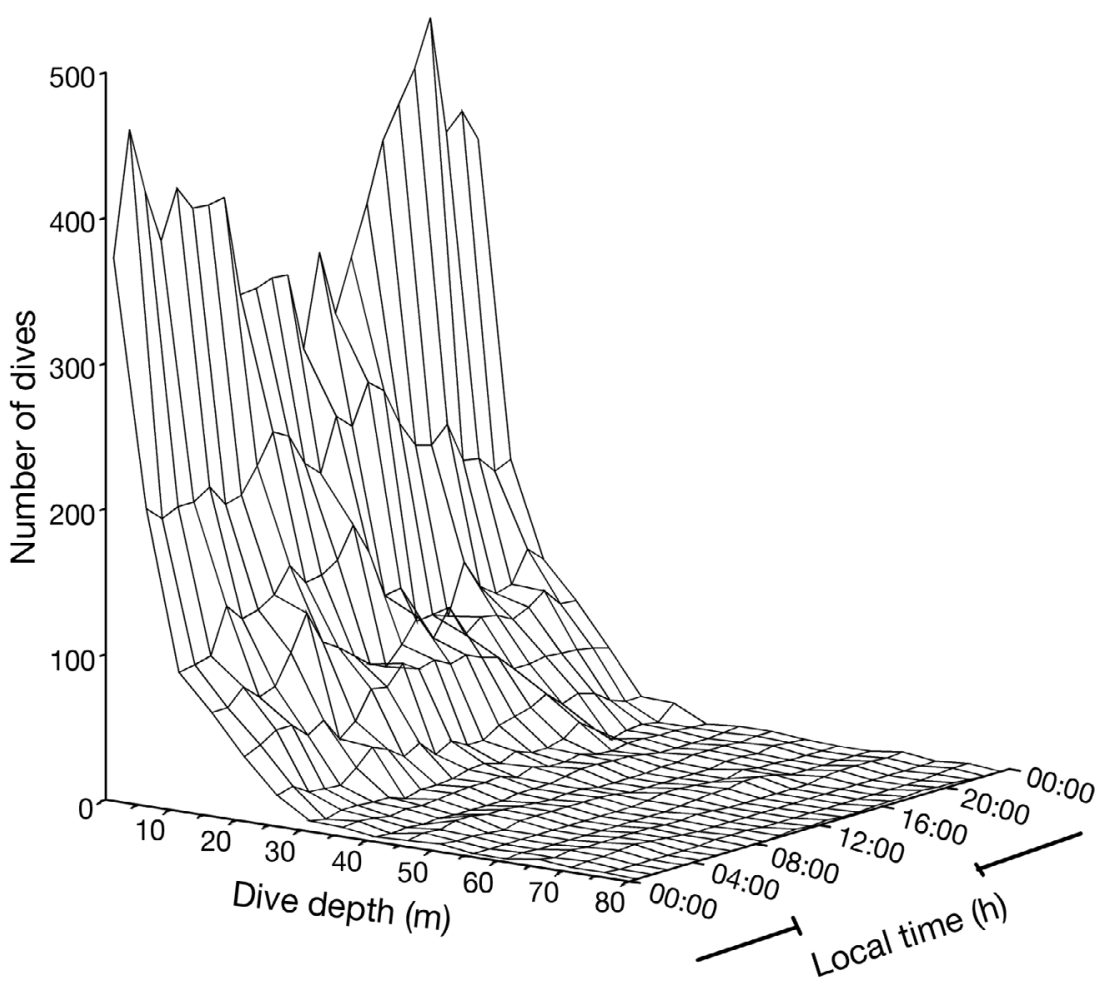

Fig. 6. Dermochelys coriacea. Distribution of dives in relation to time of day and dive depth in 10 gravid leatherback turtles during their inter-nesting interval in French Guiana in 2001, 2002 and 2003 ( $\mathrm{n}=6000$ dives). Solid lines along the z-axis show night-time dreds of kilometres in waters off French Guiana and neighbouring Suriname and exhibiting a dive pattern constrained by bathymetry.

\section{General dispersal patterns}

In French Guiana, leatherbacks exploit 3 main zones of the continental shelf, utilising the coastal zone (within $50 \mathrm{~km}$ of the coast), the neritic zone (within $100 \mathrm{~km}$ of the coast) and the edge of the continental shelf. There are important individual differences in the distance travelled and the diving pattern during the inter-nesting interval; yet, leatherbacks spend a similar time at sea regardless of their dispersal effort. Note here that our individuals exhibited inter-nesting intervals of similar duration and dispersal range to those of leatherbacks at other Atlantic nesting sites, whether or not they were equipped with externally attached instruments (Miller 1997, Georges et al. 2007). This indicates that the instruments have a negligible effect on that and the hourly dive frequency did not differ significantly among turtles, and averaged $31.3 \pm 6.7 \mathrm{~min}^{-1}$ and $12.5 \pm 2.6$ dives $\mathrm{h}^{-1}$, respectively (Kruskal-Wallis, $H_{6,37}=6.7, \mathrm{p}=0.35$ and $H_{6,37}=9.18, \mathrm{p}=0.16$, respectively, $\mathrm{n}=7$ turtles). Phase 2 was predominantly associated with short and shallow Type 1 dives, suggesting that the turtles were generally swimming at the surface when moving back to the nesting beach (Fig. 8b). Nevertheless, a non-negligible proportion $(13.1 \pm 3.9 \%)$ of Type 4 dives was also recorded during Phase 2.

\section{DISCUSSION}

The diving behaviour of leatherback turtles during the nesting season has been widely studied (Eckert et al. 1986, 1989, 1996, 2006, Keinath \& Musik 1993, Southwood et al. 1999, Eckert 2002, Hays et al. 2004, Reina et al. 2005, Wallace et al. 2005, Myers \& Hays 2006), but to date, only 1 study proposed the concurrent analysis of diving behaviour with dispersal patterns assessed by satellite telemetry during the nesting season (Eckert et al. 2006). Our study shows that leatherback turtles nesting in French Guiana disperse widely over the continental shelf, travelling hun-

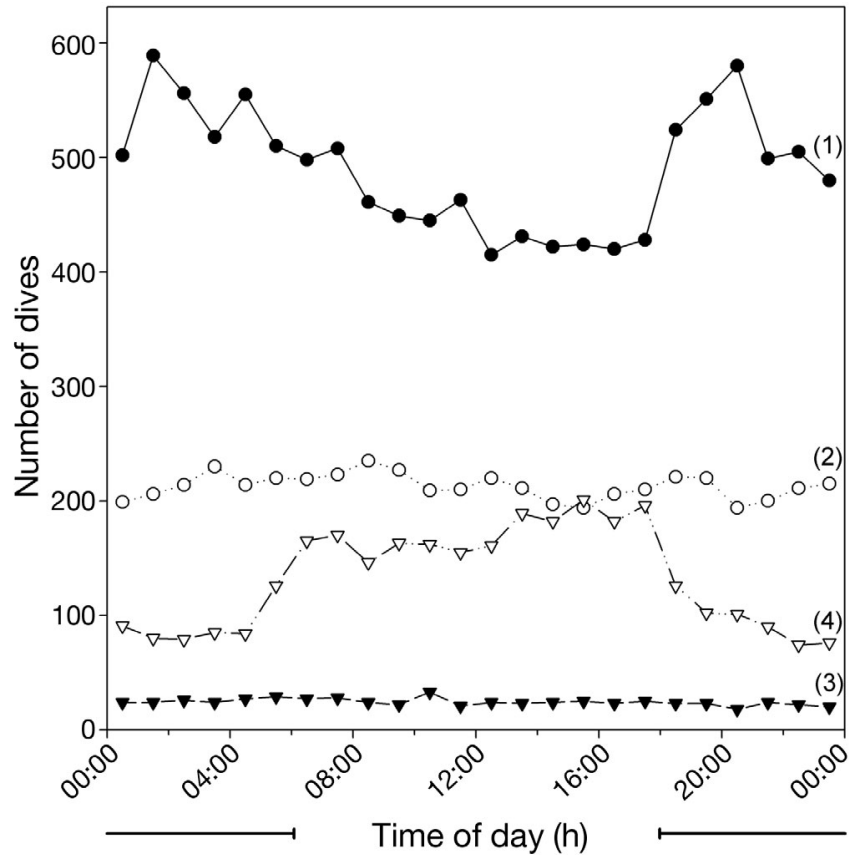

Fig. 7. Dermochelys coriacea. Hourly distribution of each dive type (labelled 1 to 4 ; see Fig. 5) performed by 10 gravid leatherback turtles during their inter-nesting interval in French Guiana in 2001, 2002 and 2003 ( $\mathrm{n}=20607$ dives). Solid lines along the $x$-axis show night-time 

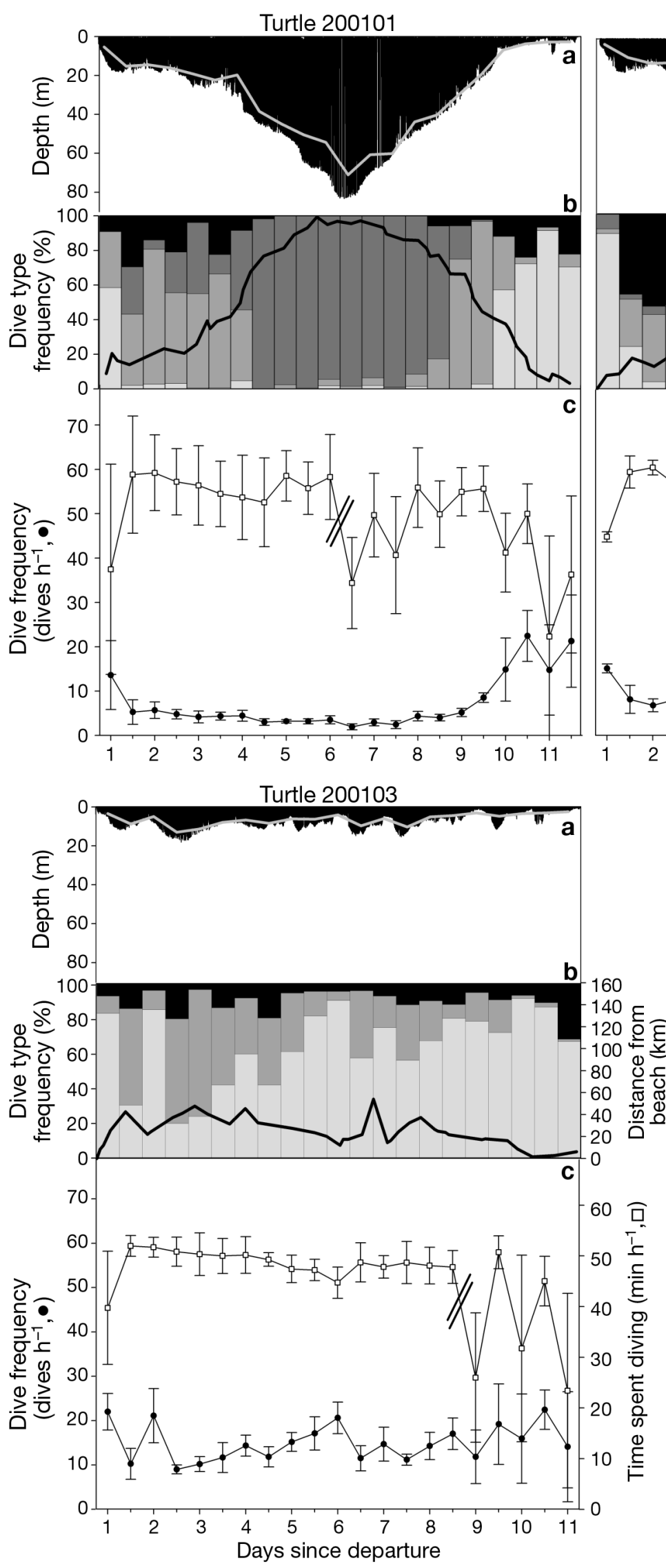

Turtle 200102

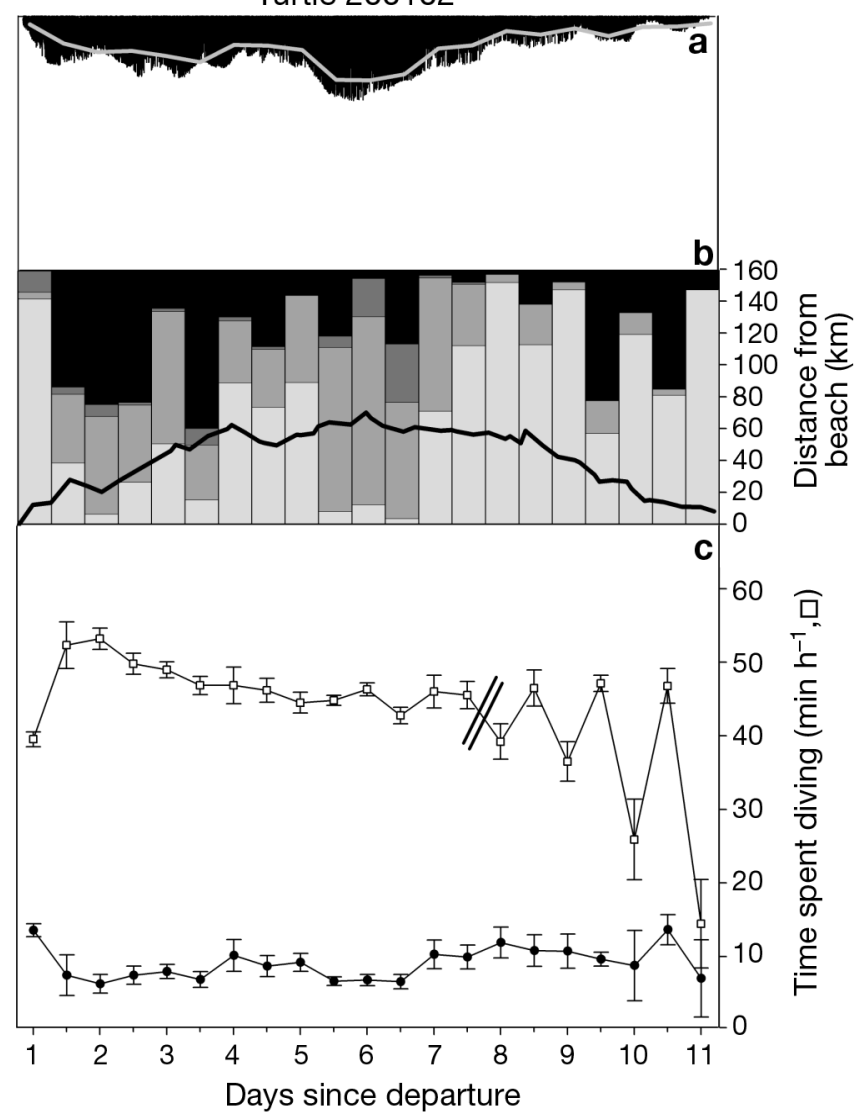

Fig. 8. Dermochelys coriacea. Diving behaviour and diving effort of 3 gravid leatherback turtles concurrently monitored with PTT and TDR during their inter-nesting interval in French Guiana in 2001. For clarity, figure presents data for only 3 leatherback turtles considered to represent the 3 dispersion patterns (coastal, neritic, edge of the continental shelf) observed in this study. Additional individual data are presented in Fig. 9. (a) Dive profile and mean depth (solid grey line); (b) daily frequency of each dive type (see Fig. 5) and distance from beach (black line); (c) diving effort (parallel lines indicate the transition between Phases 1 and 2; see 'Results')

\section{\begin{tabular}{|c} 
Dive types \\
$\square$ Type $1 \square$ Type $2 \quad \square$ Type $3 \square$ Type 4
\end{tabular}}

Fig. 9. Dermochelys coriacea. Diving behaviour and diving effort of 4 gravid leatherback turtles monitored with TDR during their inter-nesting interval in French Guiana in 2002 and 2003. (a) Dive profile and mean depth (solid grey line); (b) daily frequency of each dive type (see Fig. 5) and distance from beach (Turtle 200301 only, also equipped with a PTT; black line); (c) diving effort (parallel lines indicate the transition between Phases 1 and 2; see 'Results') 

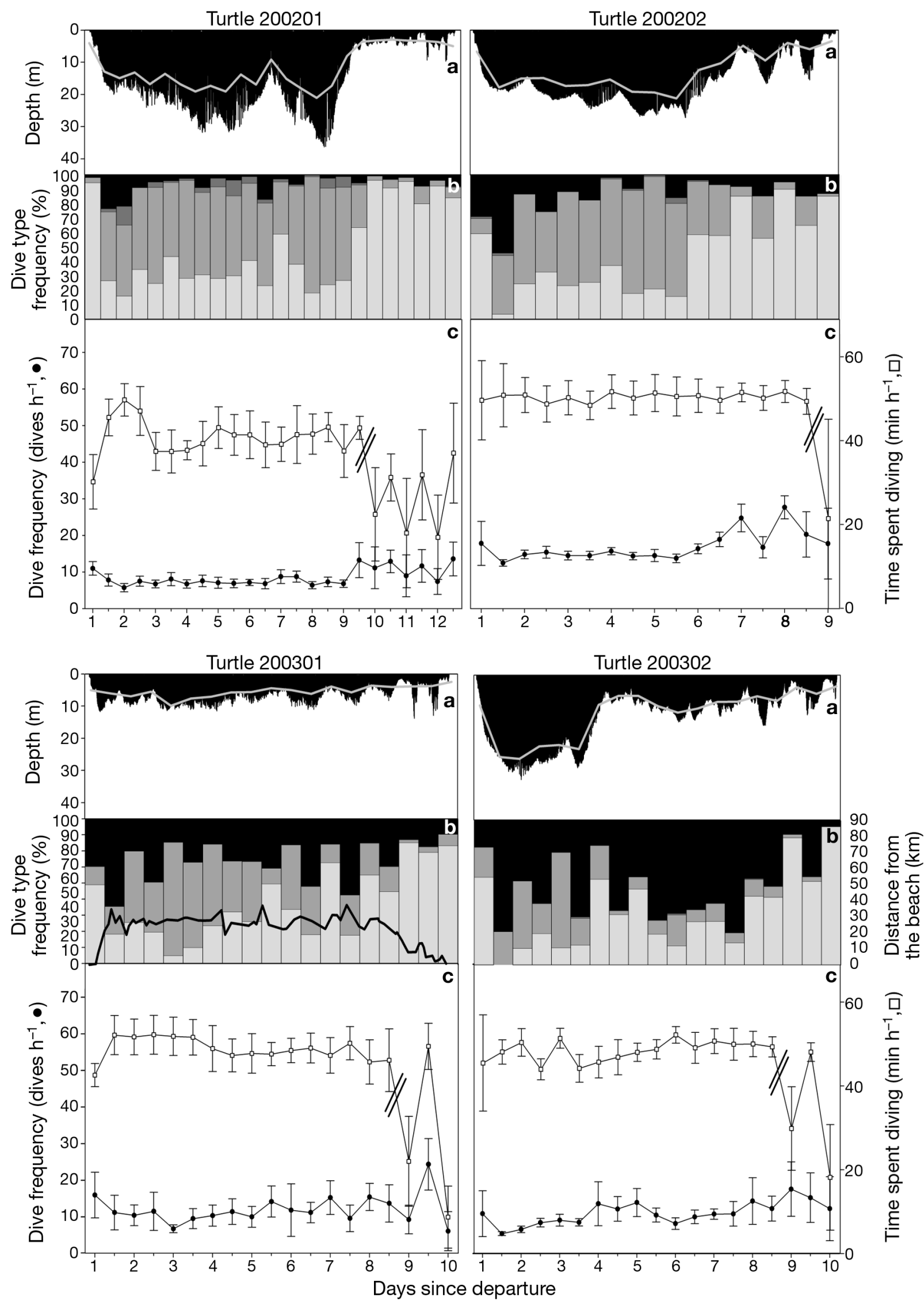
aspect of the turtles' behaviour (S. Fossette et al. unpubl.). The observed individual variations are apparently not related to an individual's size. Because sea turtles grow continuously throughout their lifespan (Chaloupka \& Musick 1997), this suggests that the duration of the inter-nesting interval and the dispersal pattern are not age-related. Instead, it might be related to individual body condition or to oceanographic conditions (see Gaspar et al. 2006), but identifying the actual causes of inter-individual variability was beyond the scope of this study.

\section{General diving patterns}

In French Guiana, leatherback diving behaviour appears to be restricted by the bathymetry of the continental shelf, with $90 \%$ of dives being shallower than $25 \mathrm{~m}$ and shorter than $10 \mathrm{~min}$. Thus, dive duration never exceeds the aerobic dive limit (ADL) estimated as between 33 and $67 \mathrm{~min}$ (Southwood et al. 1999, Hays et al. 2004, Wallace et al. 2005). Aerobic diving behaviour is supported by the weak or absent relationship between post-dive surface interval and dive duration. Similarly, leatherbacks do not appear to anticipate the duration of their dive, as suggested by the weak or absent relationship between preceding surface interval and dive duration. Such short and shallow diving activity is similar to that reported for turtles of the Eastern Pacific (Southwood et al. 1999, Reina et al. 2005, Wallace et al. 2005) and the China Sea (Eckert et al. 1996), but differs from the deep pelagic dives performed by leatherbacks in the Caribbean Sea (Eckert et al. 1989, Eckert 2002, Hays et al. 2004). Descent and ascent rates are comparable, yet lower, in French Guiana $\left(0.13 \pm 0.09 \mathrm{~m} \mathrm{~s}^{-1}\right.$ and $0.11 \pm 0.11 \mathrm{~m} \mathrm{~s}^{-1}$, respectively) than in the Eastern Pacific (descent rate: $0.15 \pm$ $0.06 \mathrm{~m} \mathrm{~s}^{-1}$; ascent rate: $0.20 \pm 0.11 \mathrm{~m} \mathrm{~s}^{-1}$; estimated from Reina et al. 2005) and China Sea (descent rate: $0.20 \pm$ $0.05 \mathrm{~m} \mathrm{~s}^{-1}$; ascent rate: $0.20 \pm 0.04 \mathrm{~m} \mathrm{~s}^{-1}$; estimated from Eckert et al. 1996), but are much lower than those estimated in the Caribbean Sea (descent rate: $0.41 \pm$ $0.18 \mathrm{~m} \mathrm{~s}^{-1}$; ascent rate: $0.31 \pm 0.01 \mathrm{~m} \mathrm{~s}^{-1}$; estimated from Eckert 2002). As in Costa Rica (Reina et al. 2005), French Guianian leatherbacks seem to stroke continuously when moving vertically, as suggested by the similar vertical rates during descent and ascent. However, in Costa Rica, leatherback turtles maintain very low energy expenditure during the inter-nesting interval (Wallace et al. 2005) by laying motionless on the seafloor (Reina et al. 2005). In contrast, leatherbacks from French Guiana spend almost one-third of their time in the bottom phase of the dive, where they perform numerous and substantial wiggles, suggesting that they actively swim throughout the dive. This is supported by direct measurements of the actual swim speed in leatherbacks from French Guiana (H. Tanaka pers. comm.). Additionally, when swimming back to the nesting beach, leatherbacks from French Guiana move to the proximity of the shore in the last days of the inter-nesting interval, presumably in anticipation of egg laying. Such patterns may also allow gravid turtles to cope with potential early egg-laying. The observation of a similar behaviour in leatherback turtles nesting in Gabon (Georges et al. 2007), on the other side of the Atlantic basin, is consistent with the fact that the duration of the inter-nesting interval is restricted by the timing of egg-maturation. In short, leatherbacks appear to adopt 1 of at least 2 strategies during their inter-nesting intervals, depending on their nesting site: the 'Pacific strategy', which consists of reduced swimming activity in order to limit energy expenditure between 2 consecutive ovi-positions, and the 'Atlantic strategy', in which leatherbacks dive and swim almost continuously throughout the inter-nesting interval while dispersing extensively, probably for feeding (Eckert et al. 1989, 2006, Myers \& Hays 2006, this study). These 2 strategies may be linked to local oceanographic conditions, with local food availability probably shaping the behaviour at the different nesting sites, as also reported for green turtles Chelonia mydas (Hays et al. 2002).

\section{Combined analysis}

The bathymetry of Guiana's continental shelf is not precisely known because of the continual influence of Amazon-derived mud banks on its morphology (Anthony \& Dolique 2004), but depth generally increases gradually with distance from the coast (Fig. 1). In our study, leatherback turtles dived deeper as they moved away from the coast, implying that they tend to follow the topography of the seabed, as has been suggested for populations in the China Sea (Eckert et al. 1996). This is supported by occasional, direct observations of well-adhered but fresh mud on the carapace of nesting leatherbacks in French Guiana (S. Fossette \& J. Y. Georges pers. obs.), suggesting that the mud was acquired some appreciable time before hauling out.

One striking finding of our study is that despite the high inter-individual variability in dispersal effort, all leatherback individuals spent the same amount of time diving ( $80 \%$ of their time spent at sea). Indeed, we found that during the first $75 \%$ of the inter-nesting interval, leatherbacks dived on average $47 \mathrm{~min} \mathrm{~h}^{-1}$ with remarkable consistency among individuals; in contrast, they exhibited a lower and more variable diving effort thereafter when returning to the coast. Similarly, Southwood et al. (1999) identified 2 phases in the 
diving behaviour of leatherbacks in Costa Rica, with a first phase characterised by relatively deep and long dives compared with the rest of the inter-nesting interval. Additionally, we found that the shapes of the dives changed according to the 2 phases defined above and to distance from the nesting beach.

\section{Close to the nesting beach}

Immediately after leaving the beach and when swimming back to their nesting site, leatherbacks mainly perform shallow ( $5 \mathrm{~m}$ depth) Type 1 dives. These dives were the most abundant in all inter-nesting intervals. Comparable dive types have been reported for green Chelonia mydas and loggerhead Caretta caretta turtles (Minamikawa et al. 1997, Hochscheid et al. 1999, Hays et al. 2001, Houghton et al. 2002), as well as for leatherbacks (Eckert et al. 1996, Southwood et al. 1999, Eckert 2002, Reina et al. 2005, Wallace et al. 2005), and have been interpreted as travelling dives (Papi et al. 1997, Eckert 2002, Reina et al. 2005). Type 1 dives may contribute to optimal travelling behaviour, as animals avoid unstable conditions at the sea surface (e.g pitching and rolling due to wave action) and reduce surface drag so that transport costs are minimized (Minamikawa et al. 2000). Type 1 dives mostly appeared at night, with peaks at the beginning of the night (19:00 to 21:00 h) and later (02:00 h), suggesting that leatherbacks may travel more at these times. In contrast, Eckert (2002) suggested that in the Caribbean Sea, leatherbacks may perform most of their horizontal movements during the middle of the day.

\section{In the coastal zone}

Within the first $12 \mathrm{~h}$ of departure, the shape of dives changes according to the dispersal mode: in addition to the travel-like Type 1 dives, leatherbacks remaining in the coastal zone (within $50 \mathrm{~km}$ of the coast) also performed dives of similar shape but slightly greater depth (15 m, Type 2 dives), suggesting that travelling also occurs at greater depths. These Type 2 dives have a particularly slow $\left(0.08 \mathrm{~m} \mathrm{~s}^{-1}\right)$ and progressive ascent to the surface compared with other dives, similar to the 'S-shaped' dives described for green and loggerhead turtles by Minamikawa et al. (1997), Hochscheid et al. (1999), Hays et al. (2001) and Houghton et al. (2002). In green and loggerhead turtles, the slow and progressive ascent has been interpreted as a passive locomotion resulting from positive buoyancy. However, contrary to green and loggerhead turtles, the small lung volume of leatherbacks is probably not involved in buoyancy control (Minamikawa et al. 1997). This pro- gressive ascent may also correspond to prey search and/or capture, as suggested for other diving predators (e.g. Ropert-Coudert et al. 2001). In the case of leatherback turtles in French Guiana, the nesting season coincides with the peak of the Amazonian influence, resulting in rings of Amazonian waters crossing the continental shelf (Froidefond et al. 2002) and enhancing biological productivity. This includes the production of gelatinous plankton, whose relatively large individual size and quantity may make a potentially significant contribution to the marine food web over the continental shelf (Fromard et al. 2004), particularly for leatherbacks, which predominantly feed on jellyfish (James \& Herman 2001). Massive strandings of jellyfish of the genus Rhizostoma and occasionally Aurelia are regularly observed on Awala-Yalimapo Beach during the nesting season (up to several hundred individuals on the $2 \mathrm{~km}$ long beach) (S. Fossette \& J. Y. Georges pers. obs.). Both species have been reported to be common prey for leatherbacks in the Atlantic (James \& Herman 2001), supporting the hypothesis that leatherbacks may encounter profitable food conditions during their inter-nesting intervals in French Guiana, as reported for neighbouring Caribbean sites (Eckert et al. 1989, 2006, Myers \& Hays 2006).

In the neritic zone and continental shelf edge

When moving further from the coast over the continental shelf, leatherbacks maintained Type 2 dives and also performed $10 \mathrm{~m}$ Type 4 dives until they reached the edge of the continental shelf, at which time Type 4 dives were replaced by Type 3 dives. Type 3 and Type 4 dives are 'W-shaped' dives (Wilson 1995) characterised by a relatively long bottom phase, during which numerous wiggles of several metres amplitude ( $>2 \mathrm{~m}$ ) occur. These wiggles are commonly interpreted as corresponding to prospecting and foraging behaviours (e.g. Schreer et al. 2001), supporting the hypothesis that leatherbacks may attempt to feed over the continental shelf. Type 4 dives mostly occurred during the day, suggesting that if they were associated with prospecting and foraging, leatherbacks may feed on gelatinous prey during daytime. If this was the case, the French Guianian situation would differ from that of the Caribbean, where leatherbacks are supposed to be nocturnal feeders (Eckert et al. 1989). Such a difference may explain why leatherbacks travel predominantly during the night in French Guiana (this study) but during the day in the Caribbean Sea (Eckert 2002).

Inter-site differences may also result from local bathymetry. In the deep Caribbean Sea, jellyfish may only be accessible to leatherbacks at night as they migrate to the surface, whereas the relatively shallow water 
depths of the continental shelf in French Guiana restrict jellyfish vertical movement both during day- and nighttime. Further investigations are required to clarify the behaviour and abundance of jellyfish in waters of the Guiana Shield, because nocturnal, shallow Type 1 dives may also contribute to nocturnal foraging when jellyfish migrate to the surface. In addition, if the gravid leatherbacks of French Guiana feed during the internesting intervals, this could explain why they are on average heavier than their relatives from other nesting sites (Georges \& Fossette 2006). Wallace et al. (2005) hypothesized that gravid leatherbacks in Costa Rica do not actively forage during the nesting season because they rarely approach their ADL. Leatherbacks in French Guiana also dive within their ADL, yet our results suggest that they may feed opportunistically rather than optimally (Thompson \& Fedak 2001).

Thus our combined analysis of dispersal and diving data suggests that leatherbacks may compensate for high reproductive expenditure by extensively prospecting for food during the inter-nesting intervals. However, direct evidence is required to confirm this. It could be tested using underwater video, or by measuring the energy balance or body mass changes during the internesting intervals. Further investigations are also required to clarify the observed inter-individual variability we found in the dispersal and diving patterns, and their implications in terms of individual fitness.

\section{Conservation implications}

If leatherback turtles forage or actively prospect for food during the nesting season, they may be exposed to a high risk of interaction with fisheries, particularly in the Guiana Shield where international fisheries operate (Charuau 2002). For some sea turtle populations that remain close to their nesting beach during the breeding season and exploit restricted foraging grounds, focused conservation efforts can prove tremendously successful (e.g. Hays 2004). However, in French Guiana, leatherback turtles move far away from their nesting beach during a single inter-nesting interval, and cross international borders to move into Surinamese waters. This emphasises the need for regional conservation strategies and international control of fishing practices in this area, which is heavily exploited by 2 local fisheries (Charuau 2002, Georges et al. 2007). In addition, leatherbacks exploit the entire water column, following the bathymetry of the continental shelf. As a consequence, trawlers operating in French Guianian and Surinamese waters should adopt appropriate fishing gear (e.g. Lutcavage et al. 1997, Epperly 2003) to reduce accidental captures of critically endangered leatherback turtles.
Acknowledgements. We are grateful to the Ministry of Ecology and Sustainable Development and the Direction Régionale de l'Environnement-Guyane, French Guiana. We thank all participants in sea turtle monitoring programmes developed in Awala-Yalimapo Beach (Réserve Naturelle de l'Amana, Kulalasi and WWF) for logistical help in the field. We also thank D. Grémillet for his comments on the first draft. S.F. was supported by a studentship from the French Ministry of Research. Funding was provided by grants to Y.L.M. from the European FEDER program and to H.T. from the Research Fellowships of the Japan Society for the Promotion of Science for Young Scientists, the Japan Society for the Promotion of Science (14405027 and 15255003) and from the MEXT Grantin-Aid for the 21st Century COE Program 'Neo-Science of Natural History' Program at Hokkaido University. This study was conducted under CNRS Institutional License B67-482 18.

\section{LITERATURE CITED}

Anthony EJ, Dolique F (2004) The influence of Amazonderived mud banks on the morphology of sandy headlandbound beaches in Cayenne, French Guiana: a short to long term perspective. Mar Geol 208:249-264

Chaloupka MY, Musick JA (1997) Age, growth, and population dynamics. In: Lutz PL, Musick JA (eds) The biology of sea turtles. CRC Press, Boca Raton, FL, p 233-276

Charuau A (2002) Le secteur de la pêche en mer. In: (ed) Atlas illustré de la Guyane. Publications Guyanaises, Limoges, p 72-77

Cherel Y, Trembley Y, Guinard E, Georges JY (1999) Diving behaviour of female northern rockhopper penguins, Eudyptes chrysocome moseleyi, during the brooding period at Amsterdam Island (Southern Indian Ocean). Mar Biol 134:375-385

Delamare A (2005) Estimation des captures accidentelles de tortues marines par les fileyeurs de la pêche côtière en Guyane. MSc dissertation, Agrocampus de Rennes

Eckert SA (2002) Swim speed and movement patterns of gravid leatherback sea turtles (Dermochelys coriacea) at St. Croix, US Virgin Islands. J Exp Biol 205:3689-3697

Eckert SA, Nellis DW, Eckert KL, Kooyman GL (1986) Diving pattern of two leatherback sea turtles (Dermochelys coriacea) during internesting intervals at Sandy Point, St. Croix, U.S. Virgin Islands. Herpetologica 42:381-388

Eckert SA, Eckert KL, Ponganis P, Kooyman GL (1989) Diving and foraging behavior of leatherback sea turtles (Dermochelys coriacea). Can J Zool 67:2834-2840

Eckert SA, Liew HC, Eckert KL, Chan EH (1996) Shallow water diving by leatherback turtles in the South China Sea. Chelonian Conserv Biol 2:237-243

Eckert SA, Bagley D, Kubis S, Ehrhart L, Johnson C, Stewart K, DeFreese D (2006) Internesting, and postnesting movements and foraging habitats of leatherback sea turtles (Dermochelys coriacea) nesting in Florida. Chelonian Conserv Biol 5:239-248

Epperly SP (2003) Fisheries-related mortality and turtle excluder devices (TEDs). In: Lutz PL, Musick JA, Wyneken (eds) The biology of sea turtles, Vol II. CRC Press, Boca Raton, FL, p 339-354

Froidefond JM, Gardel L, Guiral D, Parra M, Ternon JF (2002) Spectral remote sensing reflectances of coastal waters in French Guiana under the Amazon influence. Remote Sens Environ 80:225-232

Fromard F, Vega C, Proisy C (2004) Half a century of dynamic coastal change affecting mangrove shorelines of French 
Guiana. A case study based on remote sensing data analyses and field surveys. Mar Geol 208:265-265

Gaspar P, Georges JY, Fossette S, Lenoble A, Ferraroli S, Le Maho Y (2006) Neglecting ocean currents can lead us up the wrong track. Proc R Soc B 273:2697-2703

Georges JY, Fossette S (2006) Estimating body mass in leatherback turtles Dermochelys coriacea. Mar Ecol Prog Ser 318:255-262

Georges JY, Guinet C, Jouventin P, Weimerskirch H (1997) Satellite tracking of seabirds: interpretation of activity pattern from the frequency of satellite locations. Ibis 139:403-405

Georges JY, Billes A, Ferraroli S, Fossette S and 6 others (2007) Meta-analysis of movements in Atlantic leatherback turtles during the nesting season: conservation implications. Mar Ecol Prog Ser 338:225-232

Hays GC (2003) A review of the adaptive significance and ecosystem consequences of zooplankton diel vertical migrations. Hydrobiologia 503:163-170

Hays GC (2004) Good news for sea turtles. Trends Ecol Evol 19:349-351

Hays GC, Akesson S, Broderick AC, Glen F and 5 others (2001) The diving behaviour of green turtles undertaking oceanic migration to and from Ascension Island: dive duration, dive profiles and depth distribution. J Exp Biol 204:4093-4098

Hays GC, Glen F, Broderick AC, Godley BJ, Metcalfe JD (2002) Behavioural plasticity in a large marine herbivore: contrasting patterns of depth utilisation between two green turtle (Chelonia mydas) populations. Mar Biol 141:985-990

Hays GC, Isaacs C, King RS, Lloyd C, Lovell P (2004) First records of oceanic dive profiles for leatherback turtles, Dermochelys coriacea, indicate behavioural plasticity associated with long-distance migration. Anim Behav 67:733-743

Hochscheid S, Godley BJ, Broderick AC, Wilson RP (1999) Reptilian diving: highly variable dive patterns in the green turtle Chelonia mydas. Mar Ecol Prog Ser 185:101-112

Houghton JDR, Broderick AC, Godley BJ, Metcalfe JD, Hays GC (2002) Diving behaviour during the internesting interval for loggerhead turtles Caretta caretta nesting in Cyprus. Mar Ecol Prog Ser 227:63-70

James MC, Herman TB (2001) Feeding of Dermochelys coriacea on Medusae in the Northwest Atlantic. Chelonian Conserv Biol 4:202-205

Keinath JA, Musick JA (1993) Movements and diving behavior of a leatherback turtle, Dermochelys coriacea. Copeia (1993):1010-1017

Lutcavage ME, Plotkin P, Witherington B, Lutz PL (1997) Human impacts on sea turtle survival. In: Lutz PL, Musick JA (eds) The biology of sea turtles. CRC Press, Boca Raton, FL, p 387-409

Miller JD (1997) Reproduction in sea turtles. In: Lutz PL, Musick JA (eds) The biology of sea turtles. CRC Press, Boca Raton, FL, p 51-73

Minamikawa S, Naito Y, Uchida I (1997) Buoyancy control in diving behaviour of the loggerhead turtle, Caretta caretta. J Ethol 15:109-118

Editorial responsibility: Rory Wilson (Contributing Editor), Swansea, UK
Minamikawa S, Naito Y, Sato K, Matsuzawa Y, Bando T, Sakamoto W (2000) Maintenance of neutral buoyancy by depth selection in the loggerhead turtle Caretta caretta. J Exp Biol 203:2967-2975

Mitani Y, Sato K, Ito S, Cameron MF, Siniff DB, Naito Y (2003) A method for reconstructing three-dimensional dive profiles of marine mammals using geomagnetic intensity data: results from two lactating Weddell seals. Polar Biol 26:311-317

Myers AE, Hays GC (2006) Do leatherback turtles Dermochelys coriacea forage during the breeding season? A combination of data-logging devices provide new insights. Mar Ecol Prog Ser 322:259-267

Papi F, Luschi P Crosio E, Hughes GR (1997) Satellite tracking experiments on the navigational ability and migratory behaviour of the loggerhead turtle Caretta caretta. Mar Biol 129:215-220

Reina RD, Abernathy KJ, Marshall GJ, Spotila JR (2005) Respiratory frequency, dive behavior and social interactions of leatherback turtles, Dermochelys coriacea, during the inter-nesting interval. J Exp Mar Biol Ecol 316: $1-16$

Rivalan $\mathrm{P}$, Prévot-Julliard AC, Choquet R, Pradel R, Jacquemin B, Girondot M (2005) Trade-off between current reproductive effort and delay to next reproduction in the leatherback sea turtle. Oecologia 145:564-574

Ropert-Coudert Y, Sato K, Kato A, Charassin JB, Bost CA, Le Maho Y, Naito Y (2000) Preliminary investigations of prey pursuit and capture by king penguins at sea. Polar Biosci 13:102-113

Ropert-Coudert Y, Kato A, Baudat J, Bost CA, Le Maho Y, Naito Y (2001) Feeding strategies of free-ranging Adélie penguins Pygoscelis adeliae analysed by multiple data recording. Polar Biol 24:460-466

Schreer JF, Kovacs KM, O'Hara Hines RJ (2001) Comparative diving patterns of pinnipeds and seabirds. Ecol Monogr 71:137-162

Southwood AL, Andrews DD, Lutcavage ME, Paladino F, West NH, George RH, Jones DR (1999) Heart rates and diving behaviour of leatherback sea turtles in the eastern Pacific Ocean. J Exp Biol 202:1115-1125

Thompson D, Fedak MA (2001) How long should a dive last? A simple model of foraging decisions by breathhold divers in a patchy environment. Anim Behav 61: 287-296

Wallace BP, Cassondra LW, Paladino FV, Morreale SJ, Lindstrom RT, Spotila JR (2005) Bioenergetics and diving activity of internesting leatherback turtles Dermochelys coriacea at Parque Nacional Marino Las Baulas, Costa Rica. J Exp Biol 208:3873-3884

Watanabe Y, Bornemann H, Liebsch N, Plötz J, Sato K, Naito Y, Miyazaki N (2006) Seal-mounted cameras detect invertebrate fauna on the underside of an Antarctic ice shelf. Mar Ecol Prog Ser 309:297-300

Wilson RP (1995) Foraging ecology. In: Williams TD (ed) The penguins. Oxford University Press, Oxford, p 81-106

Submitted: March 6, 2006; Accepted: October 19, 2006

Proofs received from author(s): April 24, 2007 